\title{
KOMPOSISI KIMIA, SENYAWA BIOAKTIF DAN ANGKA LEMPENG TOTAL PADA RUMPUT LAUT Gracilaria edulis
}

\author{
Susanti Musa ${ }^{1}$, Grace Sanger ${ }^{2}$, Henny A. Dien ${ }^{2}$ \\ ${ }^{1)}$ Mahasiswa pada Program Studi Teknologi Hasil Perikanan FPIK Unsrat Manado \\ ${ }^{2)}$ Staf pengajar pada Program Studi Teknologi Hasil Perikanan FPIK Unsrat Manado
}

\begin{abstract}
ABSTRAK
Rumput laut memiliki kandungan karbohidrat, protein, sedikit lemak dan abu, yang mana sebagian besar merupakan senyawa garam dan kalori. Penelitian ini dilakukan untuk mengetahui komposisi kimia, senyawa bioaktif dan angka lempeng total pada Gracilaria edulis. Hasil penelitian ini dilakukan pengujian 2 kali ulang. G. edulis menghasilkan metabolit primer senyawa hidrokoloid yang disebut agar. Penelitian ini menggunakan metode penelitian deskriptif eksploratif. Hasil penelitian yang diperoleh dari 12 parameter, nilai yang diperoleh rata-rata kadar air $(77,773 \%)$; protein $(39,4465 \%)$; kadar lemak (8,1081\%); karbohidrat (71,75\%); kadar abu (20,7885\%); alkaloid, saponin, flavonoid, triterpenoid menunjukkan hasil positif, sedangkan steroid menunjukkan hasil negatif dan Angka Lempeng Total (ALT) pada rumput laut Gracilaria edulis sangat rendah.
\end{abstract}

Kata Kunci: Gracilaria edulis, komposisi kimia, senyawa bioaktif, angka lempeng total.

\section{PENDAHULUAN}

Perairan Indonesia yang mempunyai $70 \%$ dari wilayah Nusantara mempunyai garis pantai lebih dari $81.000 \mathrm{Km}$ dengan $13.677 \mathrm{pu}-$ lau memiliki potensi rumput laut yang cukup besar. Di Sulawesi Utara, Rumput laut merupakan salah satu komoditi andalan yang perlu dikembangkan. Hal ini didukung oleh potensi perairan pantai sekaligus peluang menjadi pemicu peningkatan pendapatan petani nelayan. Perkiraan luas areal budidaya rumput laut di Sulawesi Utara sebesar 13.500 Ha (Winarno, 2002).

Rumput laut atau algae juga dikenal dengan nama seaweed yang merupakan bagian terbesar dari tanaman laut. Rumput laut adalah tanaman tingkat rendah yang tidak memiliki perbedaan susunan kerangka seperti akar, batang dan daun yang sejati, lebih dikenal dengan nama tumbuhan talus (Berhimpon, 2001).

Analisis proksimat berupa analisa kadar air, kadar abu, bahan kering, analisa protein kasar, lemak kasar dan analisa serat kasar. Pada setiap analisis terdapat metode-metode yang berbeda. Pada dasarnya, analisis proksimat bermanfaat dalam mengidentifikasi kandungan zat makanan dari suatu bahan pangan atau pakan yang belum diketahui sebelumnya yang selanjutnya disebut sampel. Selain dari itu, analisis proksimat merupakan dasar dari analisis lebih lanjut (Hartadi et al., 1997).
Angka lempeng total adalah angka yang menunjukkan jumlah bakteri dalam tiap-tiap 1 $\mathrm{ml}$ atau 1 gram sampel makanan yang diperiksa. Prinsip dari ALT adalah menghitung pertumbuhan koloni bakteri aerob mesofil setelah sampel makanan ditanam pada lempeng media yang sesuai dengan cara tuang kemudian dieramkan selama 24-48 jam pada suhu 35$37^{\circ} \mathrm{C}$ (Joko Wibowo Ristanto, 1989). Uji ALT merupakan metode yang umum digunakan untuk menghitung adanya bakteri yang terhadap dalam sediaan yang diperiksa.

\section{METODOLOGI PENELITIAN}

\section{Waktu dan Tempat Penelitian}

Penelitian ini dilaksanakan pada bulan Februari sampai Mei 2017. Sampel Gracilaria edulis diperoleh dari perairan Mokupa, Kecamatan Tombariri, Kabupaten Minahasa.

\section{Bahan dan Alat}

Rumput laut, etanol, lebel, kertas Whatmen, alumunium foil, koran, akuades, kloroform, anhidrid asetat, asam sulfat pekat, serbuk magnesium, air panas, larutan $\mathrm{HCl} 2 \mathrm{~N}, \mathrm{FeCl}_{3}$, Kristal $\mathrm{K}_{2} \mathrm{SO}_{4}, \mathrm{HgO}, \mathrm{H}_{2} \mathrm{O}_{2}, \mathrm{H}_{3} \mathrm{BO}_{3}, \mathrm{NaOH}$, $\mathrm{Na}_{2} \mathrm{~S}_{2} \mathrm{O}_{3}$, (n-heksana), $\mathrm{NaOH}$, alumunium foil, Spritus, tissue, alkohol 70\%, Nutrient Agar (NA), $\mathrm{NaCl} 0,9$.

Alat-alat: toples, corong, neraca analitik (Sartorius TE 214S), gunting, erlenmeyer, rota- 
ry vacuum evaporator (IKA RV 05 Basic), tabung reaksi, batang pengaduk, timbangan, lempeng tetes, pipet tetes, pipet volumetric, pipet dengan kapasitas $1 \mathrm{ml}$, gelas beaker, neraca analitik, cawan alumunium, cawan porselen, cawan petri gelas/plastik berdiameter $90 \mathrm{~mm}$, oven, desikator, tanur listrik, soklet, kondensor, labu lemak, labu kjeldahl, labu ukur, buret, pemanas listrik, pendingin tegak, corong buchner, pompa vakum, hot plate, Autoclave, Inkubator, water bath yang beroperasi pada suhu $44-47^{\circ} \mathrm{C}$, sendok steril, tabung atau botol kapasitas $500 \mathrm{ml}$, plastik steril, Stomacher.

\section{Metode Penelitian}

Penelitian ini menggunakan metode penelitian deskriptif eksploratif. Yang bertujuan untuk menggambarkan keadaan suatu fenomena. Dalam penelitian ini tidak dimaksudkan untuk menguji hipotesis tertentu tetapi hanya menggambarkan apa adanya suatu variabel, gejala atau keadaan (Arikunto, 2002).

\section{Prosedur Penelitian}

Analisis yang dilakukan dalam penelitian ini adalah analisis proksimat, senyawa bioaktif dan angka lempeng total pada G. edulis segar. Analisis yang dilakukan meliputi kadar air, lemak, protein, abu dan karbohidrat. Analisis fitokimia meliputi alkaloid, flavonoid, tanin, saponin, triterpenoid dan steroid. Dan uji angka lempeng total (ALT).

\section{Analisis Kadar Air (AOAC 2005)}

Uji kadar air dilakukan dengan mengeringkan cawan porselen dalam oven pada suhu $105^{\circ} \mathrm{C}$ selama 20 menit. Cawan tersebut kemudian dimasukkan ke dalam desikator kemudian ditimbang. Sampel sebanyak 5 gram dimasukkan ke dalam cawan kemudian dikeringkan dalam oven bersuhu $105^{\circ} \mathrm{C}$ selama 5 jam. Sampel kemudian dimasukkan ke dalam desikator kemudian ditimbang. Kadar air ditentukan dengan rumus:

Ket.: $\mathrm{B}_{0}=$ Berat cawan kosong (gram)

$$
\text { Kadar Air }(\%)=\frac{B_{2}-B_{0}}{B_{1}-B_{0}} \times 100 \%
$$

$\mathrm{B}_{1}=$ Berat cawan yang diisi dengan sampel (gram)

$\mathrm{B}_{2}=$ Berat cawan sampel yang sudah dikeringkan (gram).

\section{Analisis Kadar Protein (AOAC 2005)}

Tujuan analisis protein, yaitu untuk menentukan kandungan protein kasar (crude protein) pada suatu bahan. Tahapan yang dilakukan dalam analisis protein terdiri dari tiga tahap, yaitu destruksi, destilasi, dan titrasi. a. Tahap destruksi

Sampel sebanyak 0,4 gram dimasukkan ke dalam tabung Kjeldahl $100 \mathrm{ml}$, ditambah 0,4 gram selenium dan $10 \mathrm{ml} \mathrm{H}_{2} \mathrm{SO}_{4}$ pekat. Tabung yang berisi larutan tersebut dimasukkan ke dalam alat destruksi selama 1 jam pada suhu $400^{\circ} \mathrm{C}$. Proses destruksi dilakukan sampai larutan berwarna hijau jernih.

b. Tahap destilasi

Larutan hasil destruksi dilarutkan dengan akuades dalam labu takar $10 \mathrm{ml}$ lalu dimasukkan ke dalam alat destilasi dan ditambah $10 \mathrm{ml} \mathrm{NaOH} 40 \%$. Cairan dalam ujung tabung kondensor ditampung dalam erlenmeyer $125 \mathrm{ml}$ yang berisi larutan $50 \mathrm{ml} \mathrm{H}_{3} \mathrm{BO}_{3}$ dan 2 tetes indikator (cairan methyl red dan bromo cresol green). Destilasi dilakukan sampai diperoleh larutan berwarna hijau kebiruan.

c. Tahap titrasi

Titrasi dilakukan menggunakan $\mathrm{HCl} 0,1 \mathrm{~N}$ sampai warna larutan dalam erlenmeyer berubah menjadi merah muda. Volume titran yang diperoleh kemudian dibaca dan dicatat.

\section{Analisis Kadar Lemak (AOAC 2005)}

Sampel sebanyak 5 gram $\left(\mathrm{W}_{1}\right)$ dimasukkan ke dalam selongsong lemak kemudian dimasukkan ke dalam ruang ekstraktor tabung soxhlet dan bagian atas disambungkan dengan kondensor sedangkan bagian bawah tabung soxhlet disambungkan dengan labu lemak yang sudah ditimbang beratnya $\left(\mathrm{W}_{2}\right)$. Labu lemak berisi pelarut $\mathrm{n}$-heksana yang dipanaskan pada suhu $40^{\circ} \mathrm{C}$ menggunakan pemanas listrik selama 6 jam. Pelarut $n$-heksana yang tertampung dalam labu lemak kemudian didestilasi hingga menguap sempurna, kemudian labu lemak dikeringkan dalam oven pada suhu $105{ }^{\circ} \mathrm{C}$, kemudian labu lemak dimasukkan ke dalam desikator sampai beratnya konstan dan ditimbang $\left(\mathrm{W}_{3}\right)$. Kadar lemak ditentukan dengan rumus:

$$
\begin{aligned}
\text { Ket.: } & \mathrm{W}_{1}=\text { Berat sampel }(\text { gram }) \\
\mathrm{W}_{2} & =\text { Berat labu lemak kosong }(\text { gram }) \\
\mathrm{W}_{3} & =\text { Berat labu lemak dengan lemak }(\text { gram }) .
\end{aligned}
$$$$
\operatorname{Kadar} \operatorname{Lemak}(\%)=\frac{\mathrm{W}_{3}-\mathrm{W}_{2}}{\mathrm{~W}_{1}} \times 100 \%
$$

\section{Analisis Kadar Abu (AOAC 2005)}

Cawan pengabuan dikeringkan dalam oven selama 1 jam pada suhu $105^{\circ} \mathrm{C}$, kemudian dimasukkan ke dalam desikator dan ditimbang. Sampel sebanyak 5 gram dimasukkan ke dalam cawan pengabuan dan dipijarkan hingga tidak 
berasap, kemudian dimasukkan dalam tanur pengabuan dengan suhu $600^{\circ} \mathrm{C}$ selama 6 jam kemudian dimasukkan ke dalam desikator dan ditimbang.

$$
\begin{aligned}
\text { Ket.: } & \mathrm{B}_{0}=\text { Berat sampel awal (gram) } \\
& \mathrm{B}_{1}=\text { Berat cawan kosong (gram) } \\
& \mathrm{B}_{2}=\text { Berat cawan dengan sampel setelah ditanur (gram). }
\end{aligned}
$$$$
\operatorname{Kadar} \mathrm{Abu}(\%)=\frac{\mathrm{B}_{2}-\mathrm{B}_{1}}{\mathrm{~B}_{0}-\mathrm{B}_{1}} \times 100 \%
$$

\section{Analisa Fitokimia}

Rumput laut segar dicuci dengan air tawar untuk menghilangkan kotoran, lumut, lumpur dan pasir. Kemudian rumput laut dipotongpotong atau digunting menjadi kecil-kecil, setelah itu sampel ditimbang sebanyak $1 \mathrm{~kg}$ dan dimasukan ke dalam toples kemudian ditambahkan pelarut etanol hingga volume akhir mencapai $2000 \mathrm{ml}$ dengan perbandingan 1:2 (w/v). Hasil maserasi kemudian disaring dengan kertas saring Whatman 1 sehingga dihasilkan filtrat dan residu. Perendaman dilakukan 3 kali sampai filtrat mendekati bening. Filtrat yang diperoleh kemudian dipekatkan.

$$
\% \text { Rendemen }=\frac{\text { jumlah berat ekstra }(\mathrm{g})}{\text { jumlah berat }} \times 100
$$

\section{Alkaloid}

Uji alkaloid dilakukan dengan melarutkan dalam beberapa tetes asam sulfat $2 \mathrm{~N}$ kemudian diuji dengan 2 pereaksi alkaloid yaitu pereaksi dragendorff dan pereaksi meyer. Hasil uji positif diperoleh bila terbentuk endapan merah hingga jingga dengan pereaksi dragendorff dan endapan putih kekuningan dengan pereaksi meyer.

\section{Flavonoid}

Sejumlah sampel ditambahkan serbuk magnesium $0,1 \mathrm{mg}$ dan $0,4 \mathrm{ml}$ amil alkohol (campuran asam klorida 37\% dan etanol 95\% dengan volume yang sama) dan $4 \mathrm{ml}$ alkohol kemudian campuran dikocok. Reaksi positif ditunjukkan dengan terbentuknya warna merah, kuning atau jingga pada lapisan amil alkohol.

\section{Tanin}

Sejumlah sampel ditambahkan $\mathrm{NaOH}$ 1N kemudian diamati perubahan warnanya. Reaksi positif ditunjukkan dengan terbentuknya warna kuning.

\section{Saponin (Uji Busa)}

Saponin dapat dideteksi dengan uji busa dalam air panas. Busa yang stabil akan terus terlihat selama 5 menit dan tidak hilang pada penambahan 1 tetes $\mathrm{HCl} 2 \mathrm{~N}$ menunjukkan adanya saponin.

\section{Triterpenoid dan Steroid}

Sejumlah sampel dilarutkan dalam $2 \mathrm{ml}$ kloroform dalam tabung reaksi yang kering lalu ditambahkan 10 tetes anhidra asetat dan 3 tetes asam sulfat pekat. Reaksi positif ditunjukkan dengan terbentuknya larutan berwarna merah untuk pertama kali kemudian berubah menjadi biru dan hijau.

\section{Uji Angka Lempeng Total}

Rumput laut segar dicuci dengan air tawar yang mengalir untuk menghilangkan kotoran, lumut, lumpur dan pasir. Kemudian disaring, selanjutnya sampel rumput laut dihaluskan dengan blender, kemudian ditimbang sebanyak 10 gr.

1. Semua peralatan yang digunakan dalam analisa mikrobiologis disterilkan terlebih dahulu dengan menggunakan autoclave pada suhu $121^{\circ} \mathrm{C}$, dengan tekanan 15 psi, selama 15 menit.

2. Disiapkan tabung reaksi yang telah diberi kode, lalu diisi dengan $9 \mathrm{ml} \mathrm{NaCl} 0,9 \%$, kemudian disterilkan.

3. Sampel ditimbang $10 \mathrm{gr}$, ditambah $90 \mathrm{ml}$ larutan $\mathrm{NaCl}$ 0,9\% kemudian diblender sampai homogen. Sampel ini merupakan suspense pengencer $10^{-1}$.

4. Selanjutnya diambil $1 \mathrm{ml}$ suspense dari pengencer di atas dan dipindahkan ke dalam tabung reaksi lain yang telah berisi $0,09 \mathrm{ml}$ $\mathrm{NaCl}$ menjadi suspense pengencer $10^{-1}$. Demikian seterusnya sampai tingkat pengencer $10^{-4}$.

5. Diambil NA yang telah disterilkan dan masih dalam keadaan hangat (suhu kira-kira $37-45^{\circ} \mathrm{C}$ ) secara aseptik sebanyak $15 \mathrm{ml}$ NA dituangkan ke dalam cawan petri yang telah diberi kode, lalu tunggu sampai media tersebut mengeras.

6. Setelah NA mengeras, dari setiap pengenceran diambil masing-masing $1 \mathrm{ml}$ suspensi dan dipindahkan ke dalam media NA yang telah diberi kode, lalu dengan menggunakan batang penyebar gelas steril, suspense tersebut disebarkan di seluruh permukaan media secara merata. Sementara penyebaran suspense dilakukan, cawan petri diputar perlahan-lahan. 
7. Semua cawan petri dimasukkan ke dalam incubator dengan posisi terbalik, dan diinkubasi selama 24 jam pada suhu $37^{\circ} \mathrm{C}$.

8. Kemudian dihitung jumlah koloni pada masing-masing petri. Untuk mendapatkan hasil yang baik maka setiap pengenceran dibuat duplo. Jumlah koloni yang dihitung pada cawan petri yaitu antara 30-300 koloni dan dalam keadaan koloni bebas.

9. Setelah itu, jumlah yang diperoleh dikalikan dengan satu per tingkat pengenceran.

$$
\text { Total Koloni (rlg/g) }=\sum \text { koloni } \times \frac{1}{\text { Tingkat Pengenceran }}
$$

\section{HASIL DAN PEMBAHASAN}

\section{Analisis Proksimat Pada Gracilaria edulis}

Berdasarkan hasil analisis proksimat dengan uji kadar air, protein, lemak dan kadar abu. Dapat dilihat pada Tabel 1 di bawah ini:

Tabel 1. Hasil Analisis Kadar Air, Kadar Protein, Kadar Lemak dan Abu Pada Gracilaria edulis.

\begin{tabular}{clrrr}
\hline \multirow{2}{*}{ No } & \multirow{2}{*}{ Analisis } & \multicolumn{2}{c}{ Ulangan } & \multirow{2}{*}{ Rata-rata } \\
\cline { 3 - 4 } & & U1 (\%) & \multicolumn{1}{c}{ U2 (\%) } & \multicolumn{1}{c}{$(\%)$} \\
\hline 1. & Kadar air & 72,5165 & 71,0273 & 71,7730 \\
2. & Kadar Protein & 3,1750 & 4,7180 & 3,9465 \\
3. & Kadar Lemak & 6,8981 & 9,3181 & 8,1081 \\
4. & Kadar abu & 20,8189 & 20,7581 & 20,7885 \\
\hline
\end{tabular}

\section{Kadar Air}

Hasil yang diperoleh analisis kadar air pada rumput laut G. edulis dengan jumlah ratarata 71,773. Hasil uji kadar air pada rumput laut G. edulis berdasarkan data yang ada dapat dilihat bahwa terjadi penurunan kadar air pada rumput laut $G$. edulis yaitu pada ulangan kedua. Kadar air merupakan komponen tertinggi pada rumput laut yaitu sebanyak 89,30\% (\%bb) penelitian yang dilakukan oleh Chaidir (2007).

\section{Uji Angka Lempeng Total Kadar Protein}

Analisis protein pada G. edulis mengandung nilai rata-rata protein sebesar $3,9465 \%$ dapat dilihat pada tabel, dengan perhitungan secara basis basah, sedangkan menurut penelitian Ito \& Hori (1989) kadar protein rumput laut berkisar antara 5,35\%. Hal ini menunjukkan kesesuaian hasil analisis dengan penelitian yang dilakukan oleh Ito \& Hori (1989)

\section{Kadar Lemak}

Hasil uji kadar lemak pada rumput laut G. edulis yaitu $8,1081 \%$, dapat dilihat pada tabel di atas. Menurut Ito \& Hori (1989), kadar lemak rumput laut berkisar antara $0,2-3,8 \%$. Hal ini menunjukkan kadar lemak hasil analisis tidak sesuai dengan penelitian yang dilakukan oleh Ito \& Hori (1989).

\section{Kadar Abu}

Hasil uji kadar abu pada rumput laut $G$. edulis sebesar 20,7885\%. Menurut penelitian Ito \& Hori (1989) kadar abu pada rumput laut berkisar antara 10-50\%. Hasil kandungan abu pada hasil analisis lebih kecil dikarenakan rumput laut analisis diambil dari hasil budidaya bukan dari laut secara langsung.

\section{Kandungan Fitokimia Pada Gracilaria edulis} Hasil analisis kandungan Fitokimia $G$. edulis dengan cara maserasi menggunakan pelarut etanol 50 dan $100 \%$ dapat dilihat pada Tabel 2 di bawah ini:

Tabel 2. Hasil Uji Fitokimia Ekstrak Alga 50\% dan $100 \%$ Pada Gracilaria edulis.

\begin{tabular}{cccc}
\hline \multirow{2}{*}{ No. } & Nama Senyawa & \multicolumn{2}{c}{ Hasil Pengamatan } \\
\cline { 2 - 4 } & & $\mathbf{5 0 \%}$ & $\mathbf{1 0 0 \%}$ \\
\hline 1 & Alkaloid & + & + \\
2 & Flavonoid & + & + \\
3 & Fenolik & + & + \\
4 & Tanin & + & + \\
5 & Saponin & +- & + \\
6 & Triterpenoid/ Steroid & +- \\
\hline
\end{tabular}

\section{Alkoloid}

Identifikasi alkaloid pada sampel rumput laut G. edulis yang konsentrasi 50 dan $100 \%$ menunjukkan nilai positif, itu berarti $G$. edulis mengandung senyawa alkaloid. Hasil negatif uji alkaloid hasilnya tidak berbentuk endapan. Menurut Harborne 1987, hasil uji kualitatif alkaloid menunjukkan bahwa Sargassum crassifolium dan Gracilaria coronopifolia tidak mengandung senyawa alkaloid karena saat ditambahkan pereaksi meyer tidak terbentuk endapan.

\section{Flavonoid}

Identifikasi senyawa flavonoid pada rumput laut G. edulis dilakukan dengan menggunakan 3 pereaksi, yaitu pereaksi pertama menggunakan $\mathrm{H}_{2} \mathrm{SO}_{4} 2 \mathrm{~N}$, pereaksi kedua menggunakan $\mathrm{NaOH} 10 \%$ dan pereaksi ketiga menggunakan $\mathrm{HCl}+\mathrm{Mg}$. Pereaksi ketiga menggunakan campuran asam kuat dan logam, hal ini menunjukkan senyawa yang dihasilkan pada pereaksi ini merupakan senyawa kompleks yang dapat bereaksi dengan logam $(\mathrm{Mg})$. Sehingga dapat dikatakan bahwa G. edulis positif mengan- 
dung senyawa flavonoid dengan pereaksi asam dan basa. Pada penelitian Harborne 1987 hasil uji flavonoid $G$. coronopifolia menunjukkan hasil yang positif pada ketiga pereaksi.

\section{Tanin}

Identifikasi uji tanin pada rumput laut G. edulis menunjukkan hasil positif, hal ini dibuktikan adanya endapan berwarna hitam kebiruan atau hijau. Hasil uji dari Harborne, (1987) tanin pada sampel menunjukkan bahwa $S$. crassifolium mengandung senyawa tanin, karena saat penambahan $\mathrm{FeCl} 5 \%$ warnanya berubah.

\section{Saponin}

Identifikasi uji saponin pada G. edulis yang konsentrasi $100 \%$ dan $50 \%$ menunjukkan nilai positif, dengan terdapat buih stabil saat pengocokan dilakukan. Menurut Sari (2013) menyatakan bahwa busa yang terdapat dalam pengujian senyawa saponin menunjukkan adanya glikosida yang mampu membentuk buih dalam air, senyawa glikosida yang aglikonya berupa sapongenin (Cheek, 2005 dalam Sari 2013).

\section{Triterpenoid/Steroid}

Identifikasi senyawa triterpenoid/steroid pada $G$. edulis menunjukkan nilai positif dan uji steroid terdapat nilai negatif, karena pada uji steroid, saat ditetesin pereaksi asam sulfat pekat terjadi perubahan warna biru kehijauan yang mengindikasikan senyawa steroid dalam suatu bahan alam. Pada S. crassifolium warna biru kehijauan tampak sangat jelas oleh karena itu digolongkan kategori positif kuat (+++) sedang kan pada $G$. coronopofolia warna biru yang terbentuk samar-samar dan digolongkan pada kategori positif lemah (+) yang menyatakan bahwa steroid lain terutama terdapat dalam tumbuhan renda, tetapi kadang-kadang terdapat dalam tumbuhan tinggi.

\section{Angka Lempeng Total}

Hasil uji Angka Lempeng Total pada $G$. edulis segar dengan metode tuang dapat dilihat pada Tabel 3 berikut ini:

Tabel 3. Uji Angka Lempeng Total Pada Gracilaria edulis.

\begin{tabular}{ccc}
\hline $\begin{array}{c}\text { LAMA } \\
\text { PENYIMPANAN }\end{array}$ & ULANGAN & $\begin{array}{c}\text { NILAI ALT } \\
\text { (CFU) }\end{array}$ \\
\hline \multirow{3}{*}{24 jam/hari } & 1 & $6,8 \times 10^{1}$ \\
& 2 & $4,2 \times 10^{2}$ \\
& $2,1 \times 10^{1}$ \\
\end{tabular}

Hasi uji angka lempeng total (ALT) ini sangat rendah, sudah dapat diketahui kualitas perairan Mokupa baik, kualitas air dilihat dari karakteristik fisik, kimiawi dan biologisnya, kualitas air juga menunjukkan ukuran kondisi air relatif terhadap kebutuhan biota air dan Kualitas air seringkali menjadi ukuran standar terhadap kondisi kesehatan ekosistem (Irianto, 2013). Faktor lingkungan sangat mempengaruhi pertumbuhan dan aktivitas mikrobia. Mikrobia yang mampu menyesuaikan diri dengan lingkungan baru mempunyai sifat sangat resisten dengan lingkungan baru. Aktivitas mikroba dapat dikendalikan dengan mengatur faktor lingkungan tempat hidupnya. Faktor lingkungan tersebut meliputi faktor biotik (adanya asosiasi atau kehidupan bersama antara mikrobia).

\section{KESIMPULAN DAN SARAN}

\section{Kesimpulan}

Berdasarkan hasil penelitian analisis proksimat, uji fitokimia, dan angka lempeng total (ALT) pada Gracilaria edulis yaitu:

1. Hasil Analisis Proksimat dengan rata-rata, kadar air 71,773, protein 3,9465, lemak 8,1081, kadar abu 20,7885.

2. Hasil uji Ftokimia pada setiap senyawa menunjukkan bahwa alkaloid, flafonoid, saponin, triterpenoid, tanin positif dan steroid negatif.

3. Hasil uji Anka Lempeng Total (ALT) dari Gracilaria edulis sangat rendah.

\section{Saran}

Perlu penelitian lanjut untuk uji Fenol dan aktivitas antioksidan pada rumput laut Gracilaria edulis.

\section{DAFTAR PUSTAKA}

[AOAC] Association of Official Analitycal Chemist. 2005. Official Methods of Analysis of the Association of Official Analitycal of Chemists. Arlington, Virginia, (US): Association of Official Analitycal Chemist, Inc.

Arikunto, Suharsimi. 2002. Prosedur Penelitian Suatu Pendekatan dan Praktek. Jakarta: Rineka Cipta.

Berhimpon, S. 2001, Industri Pangan Hasil Bernilai Tinggi (Veluabe Commodities) Salah Satu Unggulan Agroindustri Sulawesi Utara. Makalah Seminar Yang Disajikan Pada PSSTI Manado, 25 Januari 2001.

Cheek DB, Wishart J, MacLennan AH, et al. Cell hydration in normally grown, the premature and the low weight for gestational age infant. 2005; 10:75.

Chaidir A. 2007. Kajian rumput laut sebagai sumber serat alternatif untuk minuman berserat [tesis]. Bogor (ID): Sekolah Pascasarjana IPB. 
Harborne, J.B., 1987. Metode Fitokimia, Edisi ke dua, ITB, Bandung.

Indriani, H. dan Sumiarsih, E. 1999. Budidaya Pengolahan dan Pemasaran Rumput Laut. PT Penebar Suadaya, Jakarta.

Irianto, dan Koes, 2013, Mikrobiologi Medis (Medical Microbiology), pp. 71-3, Penerbit Alfabeta, Bandung.

Ito K, Hori K. 1989. Seaweed: chemical compo-sition and Potentional Uses. Food Reviews International 5(1):101-144.
Sari, F.P., dan S. M. Sari. 2013. Ekstraksi Zat Aktif Antimikroba dari Tanaman Yodium (Jatropha multifida Linn) sebgai Bahan Baku Alternatif Antibiotik Alami. Fakultas Teknik Universitas Diponegoro, Semarang.

Winarno FG. 2002. Kimia Pangan Dan Gizi. Penerbit PT Gramedia. Jakarta.

Winarno FG. 1996. Teknologi Pengolahan Rumput Laut. Jakarta. Penerbit Sinar Pustaka. 